\title{
Influence of trophic ecology and spatial variation on the isotopic fingerprints of seabirds
}

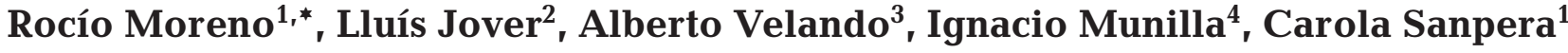 \\ ${ }^{1}$ Departamento de Biologia Animal, Facultat de Biologia, Universitat de Barcelona, Diagonal 645, 08028 Barcelona, Spain \\ ${ }^{2}$ Departamento de Salut Pública, Facultat de Medicina, Universitat de Barcelona, Casanova 143, 08036 Barcelona, Spain \\ ${ }^{3}$ Departamento de Ecoloxía e Bioloxía Animal, Facultade de Ciencias, Universidade de Vigo, 36310 Vigo, Spain \\ ${ }^{4}$ Departamento de Botánica, Facultade de Farmacia, Universidade de Santiago de Compostela, Campus Sur, \\ 15782 Santiago de Compostela, Spain
}

\begin{abstract}
Notwithstanding the potential applications of stable isotopes in feeding and migration studies, the simultaneous influence of diet, foraging behavior and spatial variation on the stable isotope signatures of seabirds is poorly understood. Many studies have interpreted their isotopic signatures without considering local baseline and prey isotopic signatures; consequently, the main factors causing isotopic differences between populations have frequently not been discerned. To examine the influence of these factors on the stable isotopic signatures of seabirds, we analyzed the $\delta^{15} \mathrm{~N}, \delta^{13} \mathrm{C}, \delta^{34} \mathrm{~S}$ and $\mathrm{Hg}$ concentrations of chick feathers of the European shag Phalacrocorax aristotelis, its main fish prey and baseline indicator organisms (mussels), all sampled in 2 sectors of northwest coastal Spain with marked differences in primary productivity. Our results show that the $\delta^{15} \mathrm{~N}$ signature and $\mathrm{Hg}$ concentration of shags are influenced by both feeding ecology and spatial variation. The $\delta^{13} \mathrm{C}$ and $\delta^{34} \mathrm{~S}$ signatures, however, mainly related to spatial differences and can thus be used as reliable geographic markers. Our findings also highlight the importance of assessing spatio-temporal variation in baseline isotopic signatures and their progressive integration through the food web. Omission of potential prey and baseline values, or application of only a single baseline to the food webs of the 2 sectors, assuming isotopic homogeneity because of geographical proximity, would have led to significantly distorted interpretations of feeding ecology of shag chicks.
\end{abstract}

KEY WORDS: ${ }^{34} \mathrm{~S} \cdot{ }^{13} \mathrm{C} \cdot{ }^{14} \mathrm{~N} \cdot$ Mercury $\cdot$ Upwelling $\cdot$ Feeding ecology $\cdot$ Atlantic Ocean $\cdot$ European shag - Resale or republication not permitted without written consent of the publisher

\section{INTRODUCTION}

Biogeochemical markers such as stable isotopes applied to marine ecosystems have provided new insights into feeding ecology and animal migration research (e.g. Oppel \& Powell 2008, Newsome et al. 2009, Ramos et al. 2009a, Votier et al. 2010). Since isotope ratios in consumer tissues reflect those of their prey in a predictable manner, isotopic signatures have been used as indicators of trophic position and food web interactions (Hobson et al. 1994, Weiss et al. 2009). Also, because differences in biogeochemical processes result in geographical isotopic variation, stable isotope analysis has permitted inferences of animal movements between water masses with different isotopic baselines (e.g. Rooker et al. 2008, Phillips et al. 2009).

Nevertheless, in spite of the potential applications of isotopic signatures of top consumers, many studies have interpreted these markers without local baseline and prey isotopic signatures, making it impossible to discern the main factors causing isotopic 
differences between populations. For this reason, interpretations based solely on isotopic differences between foraging locations or on geographic isotopic patterns described in the literature may be misleading; such differences, or lack thereof, could have a geographic basis, or be caused by other factors. Given that diet (Inger et al. 2006), foraging behavior (Cherel \& Hobson 2007) and natural biogeochemical gradients (Phillips et al. 2009) simultaneously influence the isotopic composition of marine animal tissues, sorting out the relative contributions of these factors to the variation in animal isotopic signatures remains a challenge.

In this context, several stable isotopes have been shown to offer great discriminatory power in getting at the sources of isotopic variability (Wunder et al. 2005, Moreno et al. 2010). Approaching the question in a multidisciplinary fashion is helpful (Barrett et al. 2007), and complementary tools such as Hg analysis have also proven useful in marine animal feeding studies. Since methyl-Hg is biomagnified in aquatic food webs, the consumption of prey in a higher trophic status has been related to higher Hg consumer burden (Atwell et al. 1998, Monteiro et al. 1998, Bearhop et al. 2000, Arcos et al. 2002, Anderson et al. 2010).

In the present study we examined the influence of feeding ecology and baseline spatial variation on the stable isotopic signature of seabirds. For this purpose, we chose the food web of a coastal seabird species breeding along the northwest coast of Spain, the European shag Phalacrocorax aristotelis, analysing the $\delta^{15} \mathrm{~N}, \delta^{13} \mathrm{C}, \delta^{34} \mathrm{~S}$ and $\mathrm{Hg}$ concentrations in chick feathers and fish prey species. The food webs of this area provide an ideal opportunity for analysing the simultaneous influence of spatial variation and feeding and foraging ecology on isotopic values for the following reasons: (1) the European shag breeds in small colonies scattered throughout the study area and is relatively accessible to sampling during the breeding season; (2) the European shag is a strictly piscivorous species whose main prey is well known (Álvarez 1998, Velando \& Freire 1999); (3) the breeding area that we studied can be clearly divided into 2 sectors that differ in productivity and isotopic baseline values (Fraga 1981, Figueiras et al. 2002, Bode \& Álvarez-Ossorio 2004, Bode et al. 2007); (4) geomorphological and hydrodynamic differences between these 2 sectors are known to result in differences in food web length and structure (Bode et al. 2003, 2004, Signa et al. 2008); (5) the stable isotope diettissue fractionation for the European shag has been previously studied in a fish-feeding experiment (Bearhop et al. 1999); (6) chick feathers of this species are a suitable sampling unit because they represent a delimited spatial and temporal frame (Becker et al. 1993, Sanpera et al. 2007), and because, in contrast to adult feathers, interpretation problems caused by mobility, $\mathrm{Hg}$ bioaccumulation and differences between $\mathrm{Hg}$ and isotopic turnovers are avoided (Bond 2010). In order to be able to compare and appropriately interpret the $\delta^{15} \mathrm{~N}$ of shags and prey from the 2 sectors, we calculated the shag's and prey's trophic level, which essentially normalized the $\delta^{15} \mathrm{~N}$ of shags and prey, relating it to the $\delta^{15} \mathrm{~N}$ of the bases of their respective food webs. For this purpose, the mussel Mytilus galloprovincialis, collected from both sectors, was also analyzed and used as an isotopic baseline indicator.

\section{MATERIALS AND METHODS}

The study area, located along the northwest coast of Spain, is part of the Iberian Coastal Large Marine Ecosystem, a continental shelf region of the Eastern Atlantic Ocean (see Fig. 1). Topographical features and circulation patterns play a crucial role in the dynamic of the coastal marine ecosystem of this region, with a coastline indented with rías, drowned river valleys that remain open to the sea. On the basis of oceanographic and biological features, we divided the study area into 2 sectors: the Atlantic sector (from the Miño River [41 $52^{\prime} \mathrm{N}, 8^{\circ} 52^{\prime} \mathrm{W}$ ] northward to Cape Finisterre $\left[43^{\circ} 00^{\prime} \mathrm{N}, 9^{\circ} 18^{\prime} \mathrm{W}\right]$ ), and the Cantabrian sector (to the west of Cape Estaca de Bares

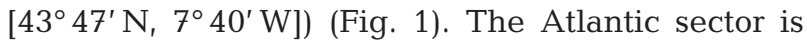
directly influenced by a coastal upwelling, which occurs from March to October, and as a result has higher productivity than the Cantabrian region, which is less influenced by upwelling dynamics (Fraga 1981, Botas et al. 1990, Figueiras et al. 2002). Moreover, such factors as river discharge and other oceanographic characteristics of the Atlantic coast maintain higher levels of productivity in the Atlantic sector. An increase of planktonic $\delta^{13} \mathrm{C}$ and $\delta^{15} \mathrm{~N}$ has been correlated with higher levels of productivity (Bode \& Álvarez-Ossorio 2004), and plankton sampled in the Atlantic sector has shown higher isotopic values than plankton sampled in more northern zones (Bode et al. 2007).

During the breeding season of 2004, we sampled fresh adult pellets (remains of indigestible, regurgitated prey), as well as down and definitive feathers (both of which reflect isotopic signatures of prey supplied by the parents) of European shag chicks at 6 insular colonies located within the 2 sectors. These 
Fig. 1. Phalacrocorax aristotelis. Location of colonies sampled and chlorophyll a (chl a) concentrations of area during chick-rearing period in Atlantic and Cantabrian sectors of northwest Spain

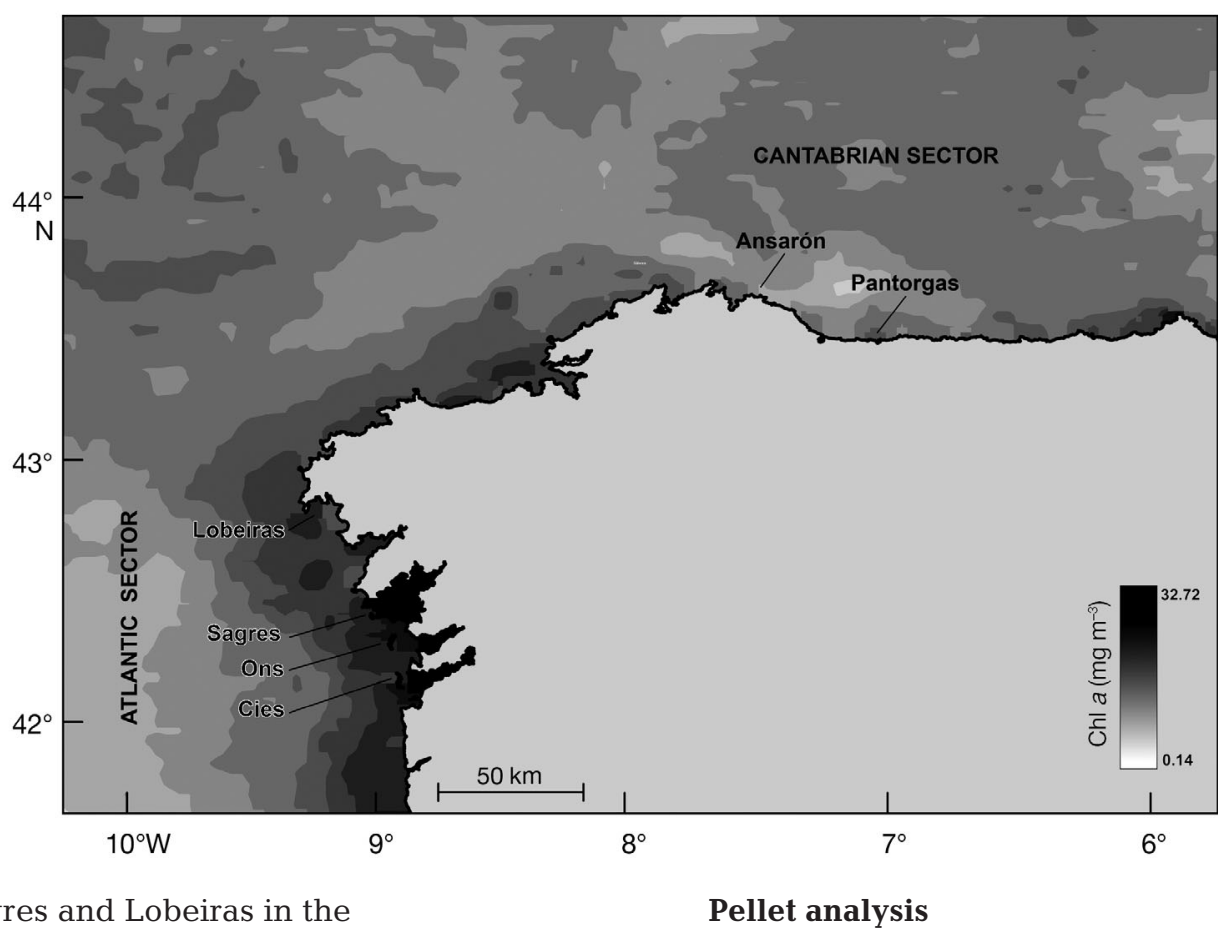

We identified prey taxa in 289 freshly regurgitated pellets produced by adults and collected in the breeding colonies during the chick-rearing period. In total, 4538 prey items were identified by means of characteristic hard remains, mostly sagittal otoliths and pharyngeal dental plates. The number of body parts was used to estimate the number of individuals (i.e. prey items) in a pellet. In the case of otoliths, this was achieved by simply dividing the number of otoliths by 2 (rounding up to the nearest whole number). Otolith pairing, the standard method of estimating prey number from otolith counts, was not feasible, as most otoliths were too eroded by the birds' digestive action (see Harris \& Wanless 1993). Diet description was based on the numerical frequency of prey items (Table 1).

\section{Stable isotope analysis $(C, N$, and $S)$}

Feathers were cleaned in a solution of $0.25 \mathrm{M}$ $\mathrm{NaOH}$, oven-dried at $60^{\circ} \mathrm{C}$ and stored in polyethylene bags until analysis. In the case of mussels, the whole soft bodies were extracted. For fish prey types, muscle samples were processed. To homogenize samples for stable isotope analysis, we ground feathers and freeze-dried mussel and fish muscle samples to an extremely fine powder using a 6750 Freezer/Mill cryogenic grinder (Spex CertiPrep), operating at liquid nitrogen temperature. Since an enrichment in 2003, Gustafson et al. 2007). 
Table 1. Phalacrocorax aristotelis. Relative frequencies (\%) of prey fishes found in fresh pellets from adult shags collected during chick-rearing period in Atlantic and Cantabrian colonies. $\mathrm{n}=$ sample size

\begin{tabular}{|c|c|c|c|c|c|c|}
\hline \multirow[t]{2}{*}{ Prey taxon } & \multicolumn{4}{|c|}{ —Atlantic sector } & \multicolumn{2}{|c|}{ — Cantabrian sector - } \\
\hline & $\begin{array}{c}\text { Cíes } \\
(\mathrm{n}=587)\end{array}$ & $\begin{array}{c}\text { Ons } \\
(\mathrm{n}=754)\end{array}$ & $\begin{array}{l}\text { Sagres } \\
(\mathrm{n}=951)\end{array}$ & $\begin{array}{l}\text { Lobeiras } \\
(\mathrm{n}=881)\end{array}$ & $\begin{array}{l}\text { Ansarón } \\
\text { (n = 625) }\end{array}$ & $\begin{array}{c}\text { Pantorgas } \\
(\mathrm{n}=776)\end{array}$ \\
\hline Atherina presbyter & 13.3 & 4.8 & 7.8 & 14.6 & 7.2 & 16.9 \\
\hline Gymnammodytes semisquamatus & 55.3 & 63.7 & 36.7 & 25.8 & 31.8 & 7.9 \\
\hline Trisopterus spp. & 1.0 & 4.6 & 9.3 & 3.6 & 0.2 & 0.9 \\
\hline Gobiidae & 11.8 & 2.5 & 3.8 & 1.6 & 10.7 & 0.9 \\
\hline Labridae & 12.1 & 18.6 & 38.2 & 52.2 & 44.8 & 68.2 \\
\hline Others & 6.5 & 5.8 & 4.2 & 2.2 & 5.3 & 5.2 \\
\hline
\end{tabular}

$\mathrm{C}, \mathrm{N}$ and $\mathrm{S}$ signature after lipid extraction has been described (Hobson \& Clark 1992, Pinnegar \& Polunin 1999, Sotiropoulos et al. 2004, Oppel et al. 2010), the $\delta^{15} \mathrm{~N}, \delta^{13} \mathrm{C}$, and $\delta^{34} \mathrm{~S}$ of prey species with different lipid content (Gymnammodytes semisquamatus, Trisopterus luscus and Labrus bergylta) were analyzed. Analysis was carried out before and after lipid extraction using several chloroform-methanol (2:1) rinses (Folch et al. 1957) to check the effect on isotopic signatures. No significant differences in tissue $\delta^{15} \mathrm{~N}$ and $\delta^{34} \mathrm{~S}$ were found after performing lipid extraction. However, $\delta^{13} \mathrm{C}$ varied depending on the species after lipid extraction process (from $-1.29 \%$ for L. bergylta to $-2.47 \%$ for $G$. semisquamatus). Thus, stable isotopes were determined on lipid-extracted samples. Weighed sub-samples of the powdered feathers, prey and mussels $\left(\sim 0.36 \mathrm{mg}\right.$ each for $\delta^{13} \mathrm{C}$ and $\delta^{15} \mathrm{~N}$, and $3.6 \mathrm{mg}$ for $\delta^{34} \mathrm{~S}$ ) were placed into tin buckets and crimped for combustion. Isotopic analyses were carried out by elemental analysis-isotope ratio mass spectrometry using a ThermoFinnigan EA 1112 Flash elemental analyzer for $\mathrm{N}$ and $\mathrm{C}$, and an EA 1108 for S, coupled to a Delta V Isotope Ratio Mass Spectrometer (Thermo Scientific) via a CONFLOIII interface.

Stable isotope ratios were expressed in conventional notation as parts per thousand (\%), using:

$$
\delta X=\left[\left(R_{\text {sample }} / R_{\text {standard }}\right)-1\right] \times 1000
$$

where $X$ is ${ }^{15} \mathrm{~N},{ }^{13} \mathrm{C}$ or ${ }^{34} \mathrm{~S}$ and $R$ is the corresponding ratio ${ }^{15} \mathrm{~N}:{ }^{14} \mathrm{~N},{ }^{13} \mathrm{C}:{ }^{12} \mathrm{C}$ or ${ }^{34} \mathrm{~S}:{ }^{32} \mathrm{~S}$.

The standards used for ${ }^{15} \mathrm{~N},{ }^{13} \mathrm{C}$ and ${ }^{34} \mathrm{~S}$ were atmospheric nitrogen (VAIR), Pee Dee Belemnite (VPDB), and Canyon Diablo Troilite (VCDT), respectively. International standards (IAEA) were inserted every 12 samples to calibrate the system and compensate for any drift over time. Precision and accuracy for $\delta^{13} \mathrm{C}$ measurement was $\leq 0.1 \%$, for $\delta^{15} \mathrm{~N} \leq-0.3 \%$ and for $\delta^{34} \mathrm{~S} \leq 0.3 \%$.
To compare the $\delta^{15} \mathrm{~N}$ signature of chick feathers and prey from the 2 sectors, we computed their trophic position using the following equation:

$$
\begin{gathered}
\text { Trophic position } \text { consumer }=\lambda+\left(\delta^{15} \mathrm{~N}_{\text {consumer }}-\right. \\
\left.\delta^{15} \mathrm{~N}_{\text {base }}\right) / \Delta \delta^{15} \mathrm{~N}
\end{gathered}
$$

where $\lambda$ is the trophic position of the organism used to estimate $\delta^{15} \mathrm{~N}_{\text {base }}$ (e.g. $\lambda=2$ for primary consumers such as mussels; Post 2002), $\delta^{15} \mathrm{~N}_{\text {consumer }}$ is measured directly, and $\Delta \delta^{15} \mathrm{~N}$ is the trophic fractionation, the enrichment in $\delta^{15} \mathrm{~N}$ per trophic level. (We used a mean fractionation of $3 \%$ derived from Vander Zanden \& Rasmusssen 2001).

\section{Mercury analysis}

Determination of $\mathrm{Hg}$ level was carried out using a PerkinElmer ELAN 6000 inductively coupled plasma optical emission spectrometer. We digested feather and prey samples ( 100 mg) using 1 to $2 \mathrm{ml} \mathrm{HNO}_{3}$ and 0.5 to $1 \mathrm{ml} \mathrm{H}_{2} \mathrm{O}_{2}$ in Teflon containers for $14 \mathrm{~h}$ at $90^{\circ} \mathrm{C}$

The accuracy of the analysis was checked by measuring certified reference tissue (Human Hair, BCR 397). Mean recoveries ranged from 80 to $92 \%$ and no corrections were made.

\section{Statistical analysis}

We routinely checked the values of stable isotope ratios and $\mathrm{Hg}$ concentrations for normality using $\mathrm{Q}-\mathrm{Q}$ plots. Hg concentrations showed skewed distributions and were normalized applying a logarithmic transformation.

Mussel data from 4 localities were compared using 1-way ANOVA. We used 2-way ANOVA to compare mean values among the 4 prey species sampled in 
the 2 sectors. Comparisons between sectors (Atlantic and Cantabrian) and among colonies within each sector were made using a nested ANOVA model for $\log \mathrm{Hg}$ and isotope values in chick feathers. We used Levene's test to check for homoscedasticity. To test for a posteriori pairwise differences, we used Tukey's procedure or a sequential Sidak adjustment for nested analysis. Statistical analysis was carried out using SPSS 15.0 (IBM).

\section{RESULTS}

Pellet data from adults (Table 1) show that, while Gymnammodytes semisquamatus and Labridae were the first and second most important diet items in the Atlantic sector, the most important prey in the Cantabrian colonies were from the Labridae, with G. semisquamatus in second place. In both sectors, Atherina presbyter was the third most important prey item.

We found significant differences in isotopic signatures between the 2 sectors for mussels, chick feathers and fish prey. Cantabrian mussels showed lower $\delta^{13} \mathrm{C}$ (Fig. $\left.2 \mathrm{a}_{;} F_{3,26}=145.9, \mathrm{p}<0.001\right)$ and $\delta^{15} \mathrm{~N}$ signatures (Table $2 ; F_{3,26}=37.9, \mathrm{p}<0.001$ ) and higher ${ }^{34} \mathrm{~S}$ values (Fig. $2 \mathrm{a}_{i} F_{3,26}=19.7, \mathrm{p}<0.001$ ) than Atlantic ones. Differences in prey fishes found in both sectors were not constant (e.g. Atherina presbyter, Gobius spp., Symphodus melops and Trisopterus luscus), and therefore there was a significant interaction between sector and species for $\delta^{15} \mathrm{~N}\left(F_{3,31}=6.79, \mathrm{p}=\right.$ $0.001)$ and $\delta^{34} \mathrm{~S}\left(F_{3,31}=3.15, \mathrm{p}=0.04\right)$, but not for $\delta^{13} \mathrm{C}$ $\left(F_{3,31}=0,97, \mathrm{p}=0.42\right)$. However, for the 3 isotopes, general trends were the same as those described for mussels: Cantabrian prey showed lower $\delta^{13} \mathrm{C}$ (Fig. 2b) and $\delta^{15} \mathrm{~N}$ signatures (Table 2) and higher $\delta^{34} \mathrm{~S}$ values (Fig. 2b) than Atlantic prey. In contrast, when computing trophic level, Cantabrian prey showed a higher trophic level (from 0.2 to 0.4 ) than Atlantic prey, except for $A$. presbyter, which occupied the same low trophic level in both sectors (Fig. 3). Although neither Cantabrian nor Atlantic prey showed differences for $\delta^{13} \mathrm{C}$ and $\delta^{34} \mathrm{~S}$, in the case of both sectors we found significant differences in both $\delta^{15} \mathrm{~N}$ and trophic level between the 2 main prey species consumed. In the Atlantic sector, Gymnammodytes semisquamatus and A. presbyter showed lower $\delta^{15} \mathrm{~N}$ values (Table 2; $F_{\text {Welch } 4,11}=93.80, \mathrm{p}<$ 0.001) and lower trophic level (Fig. $3 ; F_{4,29}=46.23$, $\mathrm{p}<0.001$ ) than T. luscus, Gobius spp. or S. melops. Also, in the Cantabrian sector, A. presbyter showed lower $\delta^{15} \mathrm{~N}$ (Table 2; $F_{4,20}=115.07, \mathrm{p}<0.001$ ) and lower trophic level (Fig. $3 ; F_{4,20}=111.6 \mathrm{p}<0.001$ )

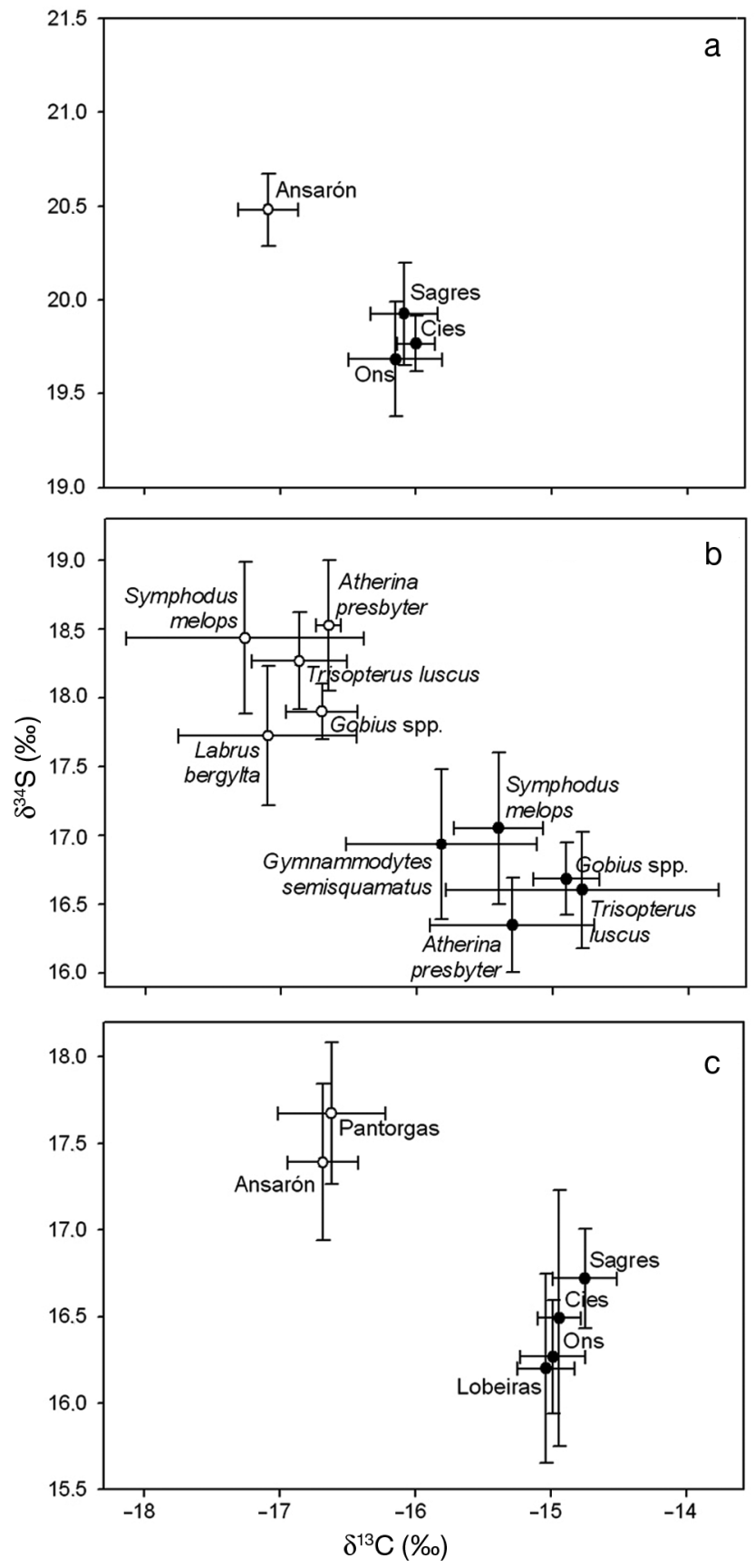

Fig. 2. Phalacrocorax aristotelis. Dual stable isotope plots of sulphur-carbon showing isotopic signatures (mean \pm SD) of (a) mussels, (b) potential prey, and (c) shag colonies sampled in the Atlantic $(\bullet)$ and Cantabrian sectors (O)

than T. luscus, Gobius spp., S. melops or Labrus bergylta. Unfortunately we could not obtain G. semisquamatus in the Cantabrian sector from fishermen or local markets. If, however, we were to estimate its trophic level based on isotopic differences between same species in both sectors, its values would be similar to the values of $A$. presbyter. Consequently, in- 
Table 2. Phalacrocorax aristotelis. Nitrogen isotopic signatures (\%o) and Hg concentrations (ng $\mathrm{g}^{-1}$ ) (mean $\pm \mathrm{SD}$ ) in mussels, shag chick feathers and potential shag prey sampled in the Atlantic and Cantabrian sectors

\begin{tabular}{|c|c|c|c|c|}
\hline & $\mathrm{n}$ & $\delta^{15} \mathrm{~N}$ & $\mathrm{Hg}$ & Median \\
\hline \multicolumn{5}{|l|}{ Baseline } \\
\hline \multicolumn{5}{|l|}{ Atlantic sector } \\
\hline Mytilus galloprovincialis & 20 & $7.80 \pm 0.22$ & - & - \\
\hline \multicolumn{5}{|l|}{ Cantabrian sector } \\
\hline Mytilus galloprovincialis & 10 & $5.82 \pm 0.25$ & - & - \\
\hline \multicolumn{5}{|l|}{ Potential prey } \\
\hline \multicolumn{5}{|l|}{ Atlantic sector } \\
\hline \multicolumn{5}{|l|}{ Ammodytidae } \\
\hline Gymnammodytes semisquamatus & 8 & $9.71 \pm 0.25$ & $119.59 \pm 17.14$ & 119.04 \\
\hline \multicolumn{5}{|l|}{ Atherinidae } \\
\hline Atherina presbyter & 8 & $10.23 \pm 0.42$ & $105.98 \pm 15.01$ & 107.18 \\
\hline \multicolumn{5}{|l|}{ Gadidae } \\
\hline Trisopterus luscus & 5 & $12.10 \pm 0.76$ & $212.08 \pm 26.47$ & 209.72 \\
\hline \multicolumn{5}{|l|}{ Gobidae } \\
\hline Gobius spp. & 6 & $11.78 \pm 0.24$ & $175.81 \pm 38.95$ & 160.42 \\
\hline \multicolumn{5}{|l|}{ Labridae } \\
\hline Symphodus melops & 3 & $11.77 \pm 0.12$ & $190.21 \pm 24.73$ & 199.52 \\
\hline \multicolumn{5}{|l|}{ Cantabrian sector } \\
\hline \multicolumn{5}{|l|}{ Atherinidae } \\
\hline Atherina presbyter & 8 & $8.21 \pm 0.25$ & $245.76 \pm 23.66$ & 245.53 \\
\hline \multicolumn{5}{|l|}{ Gadidae } \\
\hline Trisopterus luscus & 3 & $11.53 \pm 0.67$ & $762.11 \pm 141.20$ & 812.83 \\
\hline \multicolumn{5}{|l|}{ Gobidae } \\
\hline Gobius spp. & 3 & $11.03 \pm 0.15$ & $460.94 \pm 70.88$ & 489.77 \\
\hline \multicolumn{5}{|l|}{ Labridae } \\
\hline Symphodus melops & 3 & $10.43 \pm 0.38$ & $537.18 \pm 120.29$ & 467.73 \\
\hline Labrus bergylta & 4 & $11.53 \pm 0.22$ & $872.72 \pm 164.84$ & 867.9 \\
\hline \multicolumn{5}{|l|}{ P. aristotelis chick feathers } \\
\hline \multicolumn{5}{|l|}{ Atlantic sector } \\
\hline Cíes & 20 & $13.13 \pm 0.30$ & $542.97 \pm 193.61$ & 505.18 \\
\hline Ons & 15 & $13.45 \pm 0.26$ & $771.42 \pm 496.68$ & 754.14 \\
\hline Sagres & 12 & $13.56 \pm 0.22$ & $1071.59 \pm 384.91$ & 1086.05 \\
\hline Lobeiras & 13 & $13.29 \pm 0.34$ & $886.57 \pm 419.79$ & 822.34 \\
\hline \multicolumn{5}{|l|}{ Cantabrian sector } \\
\hline Ansarón & 10 & $13.71 \pm 0.48$ & $5094.45 \pm 1824.99$ & 4385.67 \\
\hline Pantorga & 15 & $13.84 \pm 0.27$ & $3087.50 \pm 1399.43$ & 3451.33 \\
\hline
\end{tabular}

terpretations of shag feeding ecology that take into account such estimation would not vary from those made based only upon the prey species included in this study.

Similarly to the geographic trend reflected by mussels and prey items, chick feathers sampled at Cantabrian colonies presented lower $\delta^{13} \mathrm{C}$ (Fig. 2c; $F_{1,79}=697.4, \mathrm{p}<0.001$ ) and higher $\delta^{34} \mathrm{~S}$ (Fig. 2c; $\left.F_{1,79}=76.7 \mathrm{p}<0.001\right)$ values than those sampled among Atlantic colonies. In contrast to the difference of $2 \%$ found for $\delta^{15} \mathrm{~N}$ in mussels, chick feathers from Cantabrian colonies showed slightly higher $\delta^{15} \mathrm{~N}$ $\left(F_{1,79}=34.5, \mathrm{p}<0.001,95 \%\right.$ CI of the difference between 0.29 and $0.59 \%$ ) than chick feathers from Atlantic colonies and, as reflected by SE (Table 2), an important overlap occurred between values from both sectors. Only chick feathers from Cíes showed a lower $\delta^{15} \mathrm{~N}$ than those from Sagres (Fig. $2 \mathrm{c}_{;} F_{4,79}=3.6$, $\mathrm{p}=0.01)$. However, once their trophic position was calculated, Cantabrian chicks shower a higher trophic level (Fig. $3 ; F_{1,79}=908.1, \mathrm{p}<0.001,95 \% \mathrm{CI}$ of the difference between 0.73 and 0.84 trophic level) than those from the Atlantic sector.

Log Hg concentrations for prey were explained by trophic position $\left(F_{1,49}=191.7, \mathrm{p}<0.001\right)$ and by sector $\left(F_{1,49}=172.8, \mathrm{p}<0.001\right)$, and were higher in the Cantabrian sector (Table 2, Fig. 4a). However, in the case of chick feathers, sector and trophic position were strongly correlated, so when trying to model its $\log \mathrm{Hg}$ concentrations (Fig. 4b), the trophic position (with a high covariance by its continuous nature) stands out as the only significant effect $\left(F_{1,78}=9.4\right.$, 
Fig. 3. Phalacrocorax aristotelis. Trophic position of shag chick feathers (circles) and potential prey species (triangle, diamond, inverted triangle, square, brick and cross, all mean \pm SD) sampled in (a) Atlantic (filled symbols) and (b) Cantabrian (open symbols) sectors. Shaded boxes indicate predicted trophic position of shags on basis of single-species fish diet considering fractionation factor of $3.6 \%$ described in a feeding experiment with captive shags (Bearhop et al. 1999)

$\mathrm{p}=0.003)$. The estimated slope for chick feathers overlaps with that found in prey data $(95 \%$ CI of estimated slopes for trophic position are 0.25 to 1.2 in chick feathers and 0.31 to 0.42 in prey). Although the difference between sectors was not significant, it is consistent with that found in prey data, and thus the possibility of a sector effect cannot be discarded (Table 2, Fig. 4).

\section{DISCUSSION}

Our study demonstrates that the $\delta^{15} \mathrm{~N}$ signature of seabirds is strongly influenced by feeding ecology and spatial variation. In contrast, the $\delta^{13} \mathrm{C}$ and $\delta^{34} \mathrm{~S}$ signatures are affected mainly by spatial differences. Although stable isotope analysis is frequently used to infer diet and migration movements of seabirds, our results highlight the difficulties inherent in studies that do not take into account the isotopic signatures of prey and baseline signatures or the interpretation of isotopic data based solely upon foraging and geographic patterns available in the literature. In our case, omission of the values of potential prey and baselines, or application of only a single baseline to

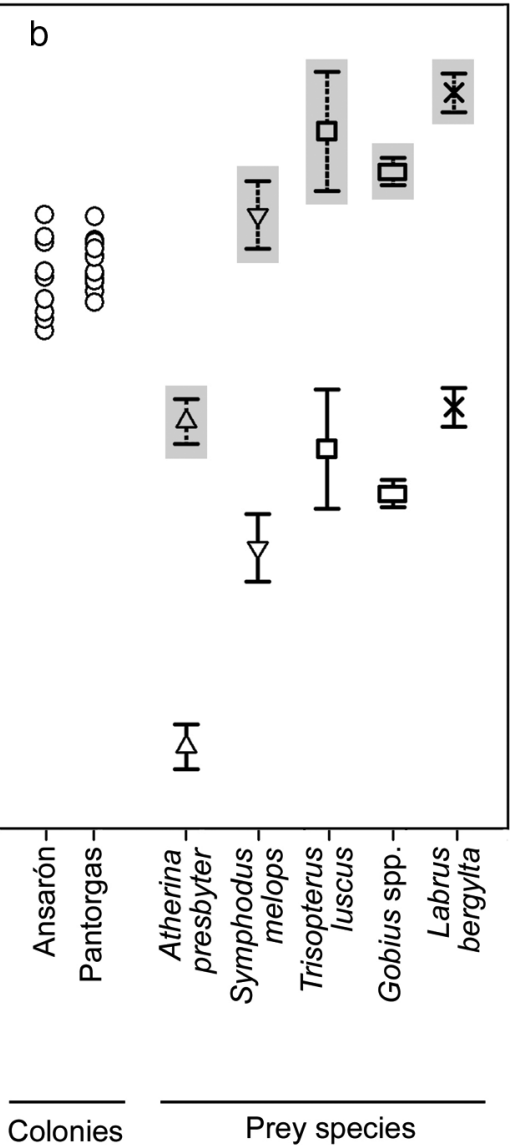

Prey species
Prey species the food webs of the 2 sectors (assuming isotopic homogeneity because of geographical closeness), would have led to significantly distorted interpretations of feeding ecology.

The $\delta^{15} \mathrm{~N}$ signatures did not differ by more than $0.5 \%$ between Atlantic and Cantabrian shags (Table 2). Without considering the baselines of both sectors, this difference could have been interpreted as occupancy of a similar trophic level. Also, in the case of $\delta^{13} \mathrm{C}$ and based on bibliographic evidence of benthic or pelagic gradients (France 1995), the higher values of Atlantic colonies could be attributed to greater reliance on resources from benthic habitats. Nevertheless, when we contextualized the isotopic values by taking into account values of local baselines and those of potential prey, an opposite view of the same landscape emerged.

In the case of $\delta^{15} \mathrm{~N}$, mussels reflected significant differences $(2 \%$ ) in the spatial variation between the isotopic baselines of the 2 sectors (Table 2). Moreover, pelagic and semi-pelagic fish species feeding on plankton (Atherina presbyter and Gymnammodytes semisquamatus) showed lower $\delta^{15} \mathrm{~N}$ values (Table 2), and, in the case of both areas, lower trophic level (Fig. 3) than omnivorous benthic and demersal 


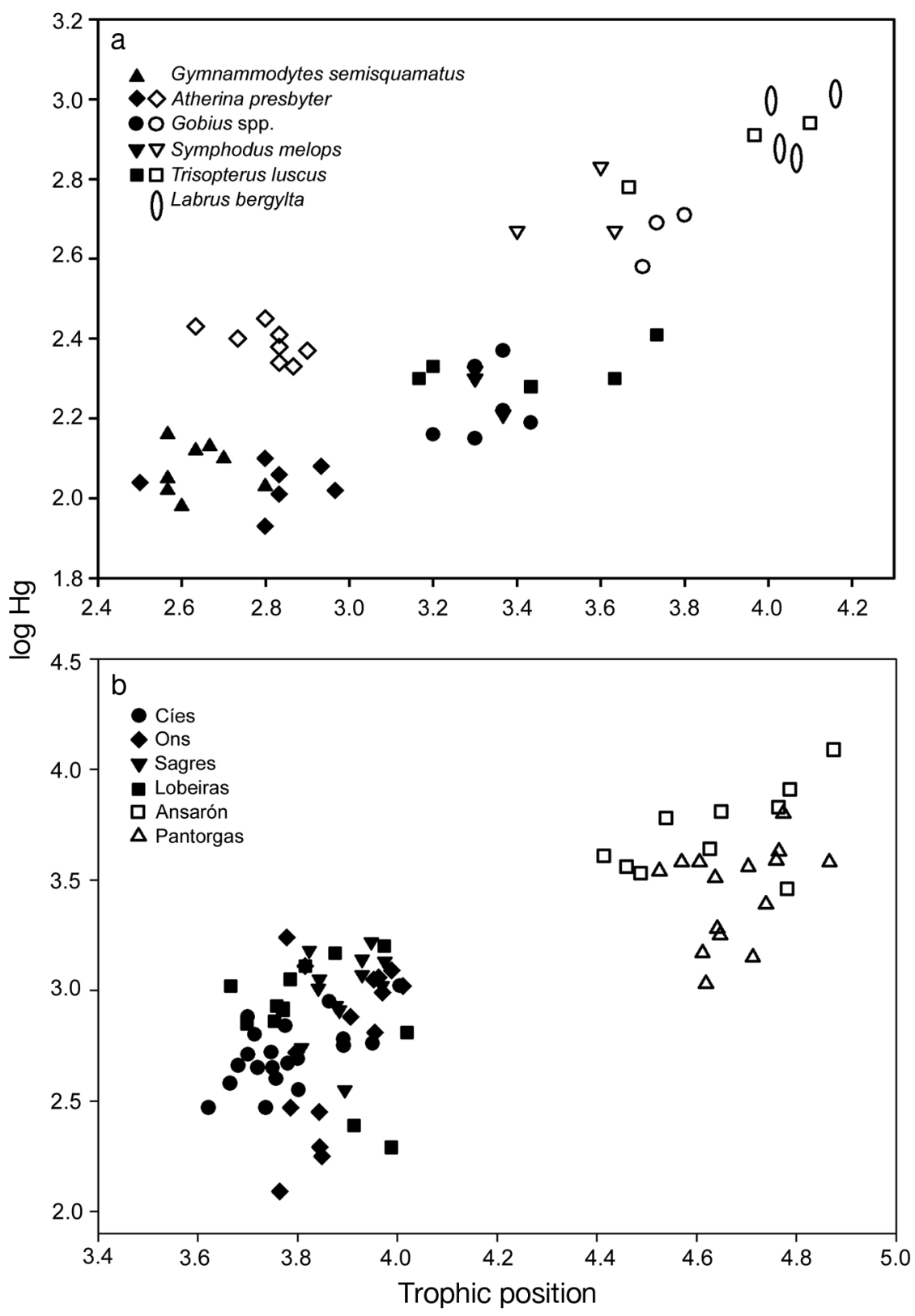

Fig. 4. Phalacrocorax aristotelis. Relationship between trophic position and $\mathrm{Hg}$ concentrations (log scale) in (a) potential prey and (b) chick feathers sampled in Atlantic (filled symbols) and Cantabrian sectors (open symbols)

This dietary description also matches the variability in the feeding habitats reflected in adult pellet composition (Table 1) and what is described in the literature (Álvarez 1998, Velando \& Freire 1999). Differences in prey availability caused by geomorphological and hydrodynamic differences between sectors has been associated with a higher adult biomass consumption of G. semisquamatus in Cíes and Ons (Velando \& Freire 1999) and with a diet based mainly on L. bergylta and S. melops at La Caladoria, another European shag breeding colony on the Cantabrian coast (Álvarez 1998).

On the basis of our results, the $\delta^{15} \mathrm{~N}$ signature, as previously suggested (Bearhop et al. 2001, Cherel \& Hobson 2007, Phillips et al. 2009), is not only affected by diet but is also largely influenced by oceanic processes. Our findings imply that, since seabirds tend to concentrate and move between habitats of enhanced and changing productivity, such as shelf edges, frontal zones and upwellings (Weimerskirch 2007), the simultaneous influence of feeding ecology and baseline spatial variation as a result of oceanic processes on their $\delta^{15} \mathrm{~N}$ signatures may be frequent. Such influence should therefore be carefully considered when interpreting isotopic variability among samples from different localities.

With regard to $\delta^{13} \mathrm{C}$, Atlantic mussels, prey and chick feathers showed higher signatures than Cantabrian samples, reflecting the same geographic tendency from baseline to consumers (Fig. 2). However, pelagic

species from sandy and rocky bottoms (Trisopterus spp., Symphodus melops, Labrus bergylta and Gobius spp.). Consequently, when the $\delta^{15} \mathrm{~N}$ signatures of shags are corrected by their respective baselines, the resultant trophic positions inform us that Atlantic chicks occupy a lower trophic level than Cantabrian chicks (3.9 vs. 4.7; Fig. 3). While shag chicks from Atlantic colonies were fed more on pelagic or semipelagic species (Fig. 3a), those from the Cantabrian colonies were fed more on benthic species (Fig. 3b). or semi-pelagic and benthic prey species in the 2 sectors were not statistically different (Fig. 2b). Thus, in this study, the differences in $\delta^{13} \mathrm{C}$ signature between sectors appeared to be influenced mainly by geography-related isotopic variation rather than by differences in diet composition. Finally, although inter-sector differences between $\delta^{34} \mathrm{~S}$ signatures were smaller than for $\delta^{13} \mathrm{C}$, mussels, prey and chick feathers also showed the same geographic trend, with Atlantic samples showing lower values than Cantabrian sam- 
ples (Fig. 2). Given that we found no differences among $\delta^{34} \mathrm{~S}$ of prey species in either of the 2 sectors (Fig. 2b), our results emphasize the usefulness of $\delta^{34} \mathrm{~S}$, in addition to $\delta^{13} \mathrm{C}$, as reliable geographic markers. Regional differences in $\delta^{34} \mathrm{~S}$ and $\delta^{13} \mathrm{C}$ baseline can be ascribed to the varying influence of natural sources. In the case of our study area, an increase of planktonic $\delta^{13} \mathrm{C}$ has been related with levels of productivity (Bode \& Álvarez-Ossorio 2004). Moreover, the rías also support large populations of macroalgae and seagrasses that are a significant source of organic matter for littoral food webs and that have been shown to have higher $\delta^{13} \mathrm{C}$ and lower $\delta^{34} \mathrm{~S}$ than plankton (Kharlamenko et al. 2001, Bode et al. 2006). Thus, both higher productivity and a greater contribution of macroalgae and seagrasses to organic matter may explain the higher $\delta^{13} \mathrm{C}$ values and lower $\delta^{34} \mathrm{~S}$ of mussels, prey and shag chicks from the Atlantic sector.

This study also indicates that the overlapping effects of the factors that simultaneously shape the isotopic signatures of seabirds may have been underestimated in previous research. Spatial and seasonal changes in the diet of the same species commonly occur in response to fluctuations in food availability, energy requirements or reproductive constraints (Knoff et al. 2002, Soto et al. 2006, Drago et al. 2009); they may result in a change in the trophic level, such as that observed in this spatial study. Such a change would involve a difference of approximately 2 to $3 \%$ in the $\delta^{15} \mathrm{~N}$ of consumer tissue, the same isotopic variation interpreted as related to geography between areas thousands of $\mathrm{km}$ apart (Wallace et al. 2006, Gómez-Díaz \& González-Solís 2007) in studies in which it was not possible to discriminate between the influence of geographic variation in baseline isotopic levels and the influence of diet.

The differences in $\delta^{13} \mathrm{C}$ between sites may also be underestimated if baseline signatures are not investigated. Without previous information, the 2 sectors sampled in the present study might have been considered as belonging to the same isotopic province within the Atlantic Ocean because they are separated by only $100 \mathrm{~km}$. However, $\delta^{13} \mathrm{C}$ signatures of chick feathers differed by $2 \%$, the same isotopic variation associated with migration between regions separated by $7000 \mathrm{~km}$ within the Atlantic (Caut et. al. 2008, Navarro et al. 2009, Ramos et al. 2009b). Cherel \& Hobson (2007) pointed out that latitudinal and inshore/offshore and benthic/pelagic gradients induce an overlap in $\delta^{13} \mathrm{C}$ values of consumers, which can lead to strong misinterpretations of foraging origins. Our results illustrate how baseline isotopic signatures reflect marine physical processes and different sources of organic matter that result in spatial changes of $\delta^{13} \mathrm{C}$ and $\delta^{34} \mathrm{~S}$ and thus can also lead to distorted interpretations.

Hg concentrations also seemed to be influenced by both feeding ecology and baseline levels characteristic of each area. Since log $\mathrm{Hg}$ concentrations of potential prey from both sectors were positively correlated with their trophic position (Fig. 4a), the higher $\mathrm{Hg}$ concentrations found in Cantabrian than in Atlantic chick feathers (Fig. 4b) seemed to be related to a greater consumption of higher-trophiclevel prey. Nevertheless, regional differences between sectors clearly had a stronger influence than trophic level on $\mathrm{Hg}$ concentrations of prey and shag chicks. In this regard, a previous monitoring program carried out in our study area reflected that mussels sampled along the Cantabrian coast showed higher $\mathrm{Hg}$ concentrations than those sampled along the Atlantic coast (Besada et al. 2011). In accordance with this result, Cantabrian prey and chick feathers in the present study were seen to contain between 2 and 5 times more $\mathrm{Hg}$ than Atlantic prey and chick feathers (Table 2). This study thus also demonstrates that, without interfering factors such as bioaccumulation related to age or sex, Hg analysis of chick feathers can be very helpful when exploring geographical patterns of pollution, and in contaminant-monitoring programs. Once again, however, absolute comparison across systems can be confounded by the simultaneous effect of trophic ecology and regional variation on Hg levels. Consequently, both factors should be considered in order to gain a fuller understanding of the mechanisms of contaminant distribution.

In summary, this study shows the importance of assessing spatial variation in baseline isotopic signatures and their progressive integration through the food web to make appropriate and conclusive interpretations of marine consumer isotopic signatures. In this regard, the use of complementary methods such as $\mathrm{Hg}$ analysis may permit more detailed interpretation of feeding ecology or geographic distribution.

Acknowledgements. We thank the 'Conselleria de Medio Ambiente' ('Xunta de Galicia' autonomous regional government) and the 'Parque Nacional de las Illas Atlánticas de Galicia' for providing the facilities to perform this study. Special thanks go to J. Bécares for help with the productivity map of the region; to C. Díez, C. Pérez, P. Pagán, L. Martínez, P. Martínez and F. Soliño for help with feather and prey sampling; and to P. Teixidor, P. Rubio, R. Roca, and E. Aracil of the 'Serveis Científico-Tècnics' for their help in the stable isotope analysis. We also thank $\mathrm{S}$. Oppel as well as 3 anonymous referees for helpful suggestions. R.M. was supported by an FPU grant ('Ministerio de Educación y Ciencia', 
Spain). Funding for this work was provided by project VEM 2003-20052 and VEM2004-08524 from the Spanish 'Ministerio de Educación y Ciencia' and CGL2008-05448-C02-C01 and CGL2008-05448-C02-C02 from the Spanish 'Ministerio de Ciencia e Innovación'.

\section{LITERATURE CITED}

Álvarez D (1998) The diet of shags Phalacrocorax aristotelis in the Cantabrian Sea, northern Spain, during the breeding season. Seabird 20:22-30

- Anderson ORJ, Phillips RA, Shore RF, McGill RAR, McDonald RA, Bearhop S (2010) Element patterns in albatrosses and petrels: influence of trophic position, foraging range, and prey type. Environ Pollut 158:98-107

> Arcos JM, Ruiz X, Bearhop S, Furness RW (2002) Mercury levels in seabirds and their fish prey at the Ebro Delta (NW Mediterranean): the role of trawler discards as a source of contamination. Mar Ecol Prog Ser 232:281-290

Atwell L, Hobson KA, Welch HE (1998) Biomagnification and bioaccumulation of mercury in an arctic marine food web: insights from stable nitrogen isotope analysis. Can J Fish Aquat Sci 55:1114-1121

Barrett RT, Camphuysen KCJ, Anker-Nilssen T, Chardine JW and others (2007) Diet studies of seabirds: a review and recommendations. ICES J Mar Sci 64:1675-1691

> Bearhop S, Thompson DR, Waldron S, Russell IC, Alexander G, Furness RW (1999) Stable isotopes indicate the extent of freshwater feeding by cormorants Phalacrocorax carbo shot at inland fisheries in England. J Appl Ecol 36: 75-84

> Bearhop S, Waldron S, Thompson DR, Furness R (2000) Bioamplification of mercury in great skua Catharacta skua chicks: the influence of trophic status as determined by stable isotope signatures of blood and feathers. Mar Pollut Bull 40:181-185

> Bearhop S, Thompson DR, Phillips RA, Waldron S and others (2001) Annual variation in great skua diets: the importance of commercial fisheries and predation on seabirds revealed by combining dietary analyses. Condor 103: 802-809

> Becker PH, Furness RW, Henning D (1993) The value of chick feathers to assess spatial and interspecific variation in the mercury contamination of seabirds. Environ Monit Assess 28:255-262

> Besada V, Andrade JM, Schultze F, González JJ (2011) Monitoring of heavy metals in wild mussels (Mytilus galloprovincialis) from the Spanish North-Atlantic coast. Cont Shelf Res 31:457-465

> Bode A, Álvarez-Ossorio MT (2004) Taxonomic versus trophic structure of mesozooplankton: a seasonal study of species succession and stable carbon and nitrogen isotopes in a coastal upwelling ecosystem. ICES J Mar Sci 61:563-571

> Bode A, Carrera P, Lens S (2003) The pelagic foodweb in the upwelling ecosystem of Galicia (NW Spain) during spring: natural abundance of stable carbon and nitrogen isotopes. ICES J Mar Sci 60:11-22

Bode A, Álvarez-Ossorio MT, Carrera P, Lorenzo J (2004) Reconstruction of trophic pathways between plankton and the North Iberian sardine (Sardina pilchardus) using stable isotopes. Scient Mar 68(1):165-178

> Bode A, Álvarez-Ossorio MT, Varela M (2006) Phytoplankton and macrophyte contributions to littoral food webs in the Galician upwelling estimated from stable isotopes. Mar Ecol Prog Ser 318:89-102

- Bode A, Álvarez-Ossorio MT, Cunha ME, Garrido S and others (2007) Stable nitrogen isotope studies of the pelagic food web on the Atlantic shelf of the Iberian Peninsula. Prog Oceanogr 74:115-131

> Bond AL (2010) Relationships between stable isotopes and metal contaminants in feathers are spurious and biologically uninformative. Environ Pollut 158:1182-1184

> Botas JA, Fernandez E, Bode A, Anadon R (1990) A persistent upwelling off the central Cantabrian coast (Bay of Biscay). Estuar Coast Shelf Sci 30:185-199

Cabana G, Rasmussen JB (1996) Comparison of aquatic food chains using nitrogen isotopes. Proc Natl Acad Sci USA 93:10844-10847

Caut S, Fossette S, Guirlet E, Angulo E, Das K, Girondot M, Georges JY (2008) Isotope analysis reveals foraging area dichotomy for Atlantic leatherback turtles. PLoS One 3: e1845

> Cherel Y, Hobson KA (2007) Geographical variation in carbon stable isotope signatures of marine predators: a tool to investigate their foraging areas in the Southern Ocean. Mar Ecol Prog Ser 329:281-287

> Drago M, Cardona L, Crespo EA, Aguilar A (2009) Ontogenic dietary changes in South American sea lions. J Zool 279:251-261

> Figueiras FG, Labarta U, Fernandez Reiriz MJ (2002) Coastal upwelling, primary production and mussel growth in the Rías Baixas of Galicia. Hydrobiologia 484: 121-131

Folch J, Lees M, Sloane-Stanley GH (1957) A simple method for the isolation and purification of total lipids from animal tissues. J Biol Chem 226:497-509

Fraga F (1981) Upwelling off the Galician coast, Northwest Spain. In: Richards FA (ed) Coastal upwelling. American Geophysical Union, Washington, DC, p 176-182

> France RL (1995) Carbon-13 enrichment in benthic compared to planktonic algae: foodweb implications. Mar Ecol Prog Ser 124:307-312

> Gómez-Díaz E, González-Solís J (2007) Geographic assignment of seabirds to their origin: combining morphologic, genetic, and biogeochemical analyses. Ecol Appl 17: 1484-1498

Gustafson L, Showers W, Kwak T, Levine J, Stoskopf M (2007) Temporal and spatial variability in stable isotope compositions of a freshwater mussel: implications for biomonitoring and ecological studies. Oecologia 152: $140-150$

Harris MP, Wanless S (1993) The diet of shags Phalacrocorax aristotelis during the chick-rearing period assessed by three methods. Bird Study 40:135-139

Hobson KA, Clark RG (1992) Assessing avian diets using stable isotopes II: factors influencing diet-tissue fractionation. Condor 94:189-197

> Hobson KA, Welch HE (1992) Determination of trophic relationships within a high Arctic marine food web using ${ }^{13} \mathrm{C}$ and ${ }^{15} \mathrm{~N}$ analysis. Mar Ecol Prog Ser 84:9-18

> Hobson KA, Piatt JF, Pitocchelli J (1994) Using stable isotopes to determine seabird trophic relationships. J Anim Ecol 63:786-798

Inger R, Ruxton GD, Newton J, Colhoun K, Robinson JA, Jackson AL, Bearhop S (2006) Temporal and intrapopulation variation in prey choice of wintering geese determined by stable isotope analysis. J Anim Ecol 75: 1190-1200 
Jennings S, Warr KJ (2003) Environmental correlates of large-scale spatial variation in the $\delta^{15} \mathrm{~N}$ of marine animals. Mar Biol 142:1131-1140

Kharlamenko VI, Kiyashko SI, Imbs AB, Vyshkvartzev DI (2001) Identification of food sources of invertebrates from the seagrass Zostera marina community using carbon and sulfur stable isotope ratio and fatty acid analyses. Mar Ecol Prog Ser 220:103-117

Knoff AJ, Macko SA, Erwin RM, Brown KM (2002) Stable isotope analysis of temporal variation in the diets of prefledged laughing gulls. Waterbirds 25:142-148

McKinney RA, Nelson WG, Charpentier MA, Wigand C (2001) Ribbed mussel nitrogen isotope signatures reflect nitrogen sources in coastal salt marshes. Ecol Appl 11: 203-214

Monteiro LR, Granadeiro JP, Furness RW (1998) Relationship between mercury levels and diet in Azores seabirds. Mar Ecol Prog Ser 166:259-265

Moreno R, Jover L, Munilla I, Velando A, Sanpera C (2010) A three-isotope approach to disentangling the diet of a generalist consumer: the yellow-legged gull in northwest Spain. Mar Biol 157:545-553

Navarro J, Forero MG, González-Solís J, Igual JM, Bécares J, Hobson KA (2009) Foraging segregation between two closely related shearwaters breeding in sympatry. Biol Lett 5:545-548

> Newsome SD, Tinker MT, Monson DH, Oftedal OT and others (2009) Using stable isotopes to investigate individual diet specialization in California sea otters (Enhydra lutris nereis). Ecology 90:961-974

Oppel S, Powell AN (2008) Assigning king eiders to wintering regions in the Bering Sea using stable isotopes of feathers and claws. Mar Ecol Prog Ser 373:149-156

Oppel S, Federer RN, O'Brien DM, Powell AN, Hollmén TE (2010) Effects of lipid extraction on stable isotope ratios in avian egg yolk: Is arithmetic correction a reliable alternative? Auk 127:72-78

Phillips RA, Bearhop S, Mcgill RAR, Dawson DA (2009) Stable isotopes reveal individual variation in migration strategies and habitat preferences in a suite of seabirds during the nonbreeding period. Oecologia 160:795-806

Pinnegar JK, Polunin NVC (1999) Differential fractionation of $\delta^{13} \mathrm{C}$ and $\delta^{15} \mathrm{~N}$ among fish tissues: implications for the study of trophic interactions. Funct Ecol 13:225-231

Post DM (2002) Using stable isotopes to estimate trophic position: models, methods, and assumptions. Ecology 83: 703-718

Ramos R, González-Solís J, Croxal JP, Oro D, Ruiz X (2009a) Understanding oceanic migrations with intrinsic biogeochemical markers. PLoS One 4:e6236

Editorial responsibility: Yves Cherel,

Villiers-en-Bois, France
Ramos R, González-Sólis J, Ruiz X (2009b) Linking isotopic and migratory patterns in a pelagic seabird. Oecologia 160:97-105

Rooker JR, Secor DH, DeMetrio G, Schloesser R, Block BA, Neilson JD (2008) Natal homing and connectivity in Atlantic bluefin tuna populations. Science 322:742-744

> Sanpera C, Ruiz X, Moreno R, Jover L, Waldron S (2007) Mercury and stable isotopes in feathers of Audouin's gulls as indicators of feeding habits and migratory connectivity. Condor 109:268-275

Signa G, Cartes JE, Solé M, Serrano A, Sánchez F (2008) Trophic ecology of the swimming crab Polybius henslowii Leach, 1820 in Galician and Cantabrian Seas: influences of natural variability and the Prestige oil spill. Cont Shelf Res 28:2659-2667

Sotiropoulos MA, Tonn WM, Wassenaar LI (2004) Effects of lipid extraction on stable carbon and nitrogen isotope analyses of fish tissues: potential consequences for food web studies. Ecol Freshw Fish 13:155-160

Soto KH, Trites AW, Arias-Schreiber M (2006) Changes in diet and maternal attendance of South American sea lions indicate changes in the marine environment and prey abundance. Mar Ecol Prog Ser 312:277-290

Vander Zanden MJ, Rasmussen JB (2001) Variation in $\delta^{15} \mathrm{~N}$ and $\delta^{13} \mathrm{C}$ trophic fractionation: implications for aquatic food web studies. Limnol Oceanogr 46:2061-2066

> Velando A, Freire J (1999) Intercolony and seasonal differences in the breeding diet of European shags on the Galician coast (NW Spain). Mar Ecol Prog Ser 188:225-236

> Velando A, Munilla I (2011) Disturbance to a foraging seabird by sea-based tourism: implications for reserve management in marine protected areas. Biol Conserv 144:1167-1174

Votier SC, Bearhop S, Witt MJ, Inger R, Thompson D, Newton $J$ (2010) Individual responses of seabirds to commercial fisheries revealed using GPS tracking, stable isotopes and vessel monitoring systems. J Appl Ecol 47:487-497

> Wallace BP, Seminoff JA, Kilham SS, Spotila JR, Dutton PH (2006) Leatherback turtles as oceanographic indicators: stable isotope analyses reveal a trophic dichotomy between ocean basins. Mar Biol 149:953-960

Weimerskirch H (2007) Are seabirds foraging for unpredictable resources? Deep-Sea Res II 54:211-223

Weiss F, Furness RW, McGill RAR, Strange IJ, Masello JF, Quillfeldt P (2009) Trophic segregation of Falkland Islands seabirds: insights from stable isotope analysis. Polar Biol 32:1753-1763

> Wunder MB, Kester CL, Knopf FL, Rye RO (2005) A test of geographic assignment using isotope tracers in feathers of known origin. Oecologia 144:607-617

Submitted: June 24, 2010; Accepted: September 23, 2011

Proofs received from author(s): November 25, 2011 